\title{
Seasonal changes in hypothalamic gonadotropin inhibitory hormone expression in the paraventricular nucleus of chukar partridge (Alectoris chukar)
}

\author{
Farzad Mohammad Rezazadeh ${ }^{1}$, Mohammad Reza Jafarzadeh Shirazi ${ }^{1,6}$, Mohammad Javad Zamiri ${ }^{1}$, \\ Mohammad Saied Salehi ${ }^{2}$, Mohammad Reza Namavar ${ }^{3}$, Amir Akhlaghi $^{1}$, Amin Tamadon $^{4}$, \\ Kazuyoshi Tsutsui ${ }^{5}$ \\ ${ }^{1}$ Department of Animal Science, College of Agriculture, Shiraz University, Shiraz, Iran. \\ ${ }^{2}$ Department of Physiology, Faculty of Biological Science, Shahid Beheshti University, Tehran, Iran. \\ ${ }^{3}$ Histomormphometry \& Stereology Research Center, and Clinical Neurology Research Center, Shiraz University of Medical \\ Sciences, Shiraz, Iran. \\ ${ }^{4}$ Stem Cells Technology Research Center, Shiraz University of Medical Sciences, Shiraz, Iran. \\ ${ }^{5}$ Department of Biology, Waseda University, Shinjuku-ku, Tokyo, Japan.
}

\begin{abstract}
Gonadotropin inhibitory hormone $(\mathrm{GnIH})$ as a hypothalamic neuropeptide inhibits the synthesis and release of gonadotropins via affecting gonadotropin releasing hormone $(\mathrm{GnRH})$ neurons and could be a key neuropeptide in regulating seasonal breeding in birds. The aim of the present study was to investigate the expression of $\mathrm{GnIH}$ in the hypothalamus of male and female chukar partridges (Alectoris chukar) during the breeding and non-breeding seasons. In breeding (May) and non-breeding (January) seasons, the brains of sexually-matured male $(\mathrm{n}=10)$ and female $(\mathrm{n}=10)$ chukar partridges were removed following fixation. Sections $(30 \mu \mathrm{m})$ were prepared from the entire diencephalon and stained immunohistochemically. GnIH-immunoreactive neurons were primarily found in paraventricular nucleus, and few positive neurons were detected in dorsomedial nucleus. The numbers of GnIHimmunoreactive neurons were significantly lower in the breeding season compared with the non-breeding season in both male and female $(\mathrm{P}<0.05)$. There were no significant differences in the number of $\mathrm{GnIH}$ neurons in paraventricular nucleus between the sexes. Gonadal weight and volume in male and female partridges were significantly higher in the breeding season. The results showed that GnIH neurons may partly contribute to the regulation of the seasonal breeding in the chukar partridge.
\end{abstract}

Keywords: gonadotropin inhibitory hormone, paraventricular nucleus, partridge, seasonal breeding.

\section{Introduction}

Reproductive processes are regulated by a variety of signals including hormones, growth factors, and environmental factors such as photoperiod. Birds use internal circadian rhythms to detect the day length. During the photosensitive phase, birds are sensitive to the light with long days stimulating LH secretion (for reviews, see Tsutsui et al., 2013, Kriegsfeld et al., 2015). For many years, gonadotropin-releasing hormone $(\mathrm{GnRH})$ was known as an only regulator of the pituitary gonadotrope activity; in 2000, however, a new neuropeptide was discovered in the hypothalamus of the
Japanese quail, and was named gonadotropin inhibitory hormone (GnIH; Tsutsui et al., 2000). Since the discovery of $\mathrm{GnIH}$, numerous studies over the past decade and a half have demonstrated that $\mathrm{GnIH}$ in birds inhibits the synthesis and release of gonadotropin by acting on the GnRH neurons and pituitary gonadotropes via its cognate receptor -GPR147 (for reviews, see Tsutsui, 2009; Tsutsui et al., 2010, 2013). GnIH and its receptor can act at multiple levels namely the brain, pituitary, and gonads (for reviews, see Bentley et al., 2009; Tsutsui, 2009; Tsutsui et al., 2010, 2013), and may be an important modulator of reproductive functions in domestic and wild birds (for reviews, see Bentley et al., 2009; Tsutsui, 2009; Tsutsui et al., 2010, 2013).

Partridges belong to the Galliformes order and Phasianidae family. Although partridges are seasonal breeders, they reproduce successfully in captivity. Chukar partridge (Alectoris chukar) is widely distributed throughout the world. The aim of the present study was to determine the effect of long (breeding season) and short days (non-breeding season) on the hypothalamic $\mathrm{GnIH}$ expression in male and female chukar partridges.

\section{Materials and Methods}

Birds

In late September, adult (1.5 years old) male and female chukar partridges (10 males and 10 females) were purchased from Taba Farm, Shiraz, Iran and transferred to the Animal Research Station of the College of Agriculture, Shiraz University, Shiraz, Iran (latitude $29^{\circ} 44^{\prime} \mathrm{N}$; longitude $52^{\circ} 37^{\prime} \mathrm{E}$; altitude $1810 \mathrm{~m}$ above sea level). The birds were kept in outdoor cages under natural photoperiods and had free access to feed and water. All procedures were carried out in accordance to the Shiraz University Guidelines for Animal Handling, and the project was approved by the Ethics Committee of Shiraz University.

\section{Brain perfusion and collection}

In the non-breeding (early January, 10.5 L:13.5 $\mathrm{D} \mathrm{h}$ photoperiod) and breeding (May, 13.5 L:10.5 D h 
photoperiod) season, five female and five male partridges per season were randomly selected and perfused at 10:00 h. The female partridges were perfused $24 \mathrm{~h}$ post-oviposition in the breeding season; the birds were anesthetized with chloroform and perfused with normal saline containing 12.5 IU heparin/ml (Rotexmedica, Trittau, Germany) through the left cardiac ventricle. The birds were then perfused with $10 \%$ neutral-buffered formalin $(\mathrm{pH}=7.2-7.4)$ diluted in phosphate-buffered saline (PBS, $0.01 \mathrm{M}$ ). The brain was dissected out and the diencephalon was kept in the same fixative solution, followed by $48 \mathrm{~h}$ incubation in $30 \%$ buffered sucrose solution, and stored at $-80^{\circ} \mathrm{C}$ until sectioning. The testes and ovaries were also dissected, weighed, and their volumes estimated by using fluid displacement of Archimedes' principle.

\section{Immunohistochemical staining of GnIH neurons}

Using a freezing microtome (Slee, Mainz, Germany), the diencephalic tissue was cut into $30-\mu \mathrm{m}$ serial coronal sections and sections were transferred to a 12-well plate containing cryoprotectant solution and stored at $-20^{\circ} \mathrm{C}$ until staining. Immunohistochemistry was performed on one set of diencephalon sections and then on sections containing paraventricular nucleus (PVN). Since the PVN is the sole source of GnIH synthesis in the avian brain (Tsutsui et al., 2010), it was identified using a chicken brain atlas (Kuenzel, 2015). To confirm the similarity of partridge and chicken brain, all sections from the third well were mounted on a slide and stained with cresyl violet. Stained sections were compared with chicken brain atlas (Fig. 1; Kuenzel, 2015). For immunohistochemistry, sections were postfixed for $10-20 \mathrm{~min}$ in $4 \%$ paraformaldehyde and washed with PBS for three times. Then, they were incubated in a blocking solution ( $1 \%$ normal goat serum, $1 \%$ bovine serum albumin, $0.3 \%$ Triton $\mathrm{X}-100$ in PBS) for $30 \mathrm{~min}$. The sections were then incubated with rabbit anti-quail GnIH (SIKPSAYLPLRFamide) antibody (1:5000 in blocking solution) overnight at $4^{\circ} \mathrm{C}$ and washed with PBS for three times. The antibody supplied by K. Tsutsui, Waseda University, Tokyo, Japan which cross reacts with the fragment of variety vertebrate $\mathrm{GnIH}$ such as chicken (Chowdhury et al., 2012), goat (Jafarzadeh Shirazi et al., 2014) and rat (Jafarzadeh Shirazi et al., 2013). The sections were subsequently incubated with the FITC-labeled goat antirabbit immunoglobulin G (Invitrogen, Carlsbad, CA, USA; 1:50 in the blocking solution) for $60 \mathrm{~min}$. Finally, the sections were washed with PBS and covered with Dako fluorescence mounting medium (Dako, Glostrup, Denmark). Immunoreactive (-ir) $\mathrm{GnIH}$ neurons were counted in whole PVN by a blinder observer in three sections per animal using a fluorescence microscope (Nikon, Japan). Two sets of control sections were used, one by omitting the primary antibody (negative control) and the other for the specificity of the primary antibody. The specificity of the primary antibody was assessed by adsorption tests of the antibody with synthetic quail $\mathrm{GnIH}$ in a saturating concentration $(20 \mu \mathrm{g} / \mathrm{ml}$; Fig. 2A), synthetic human NPFF (FLFQPQRFamide) at $10 \mu \mathrm{g} / \mathrm{ml}$ (Fig. 2B) and synthetic human KiSS-10 (YNWNSFGLRFamide) at $10 \mu \mathrm{g} / \mathrm{ml}$ (Fig. 2C; supplied by K. Tsutsui, Tokyo, Japan).

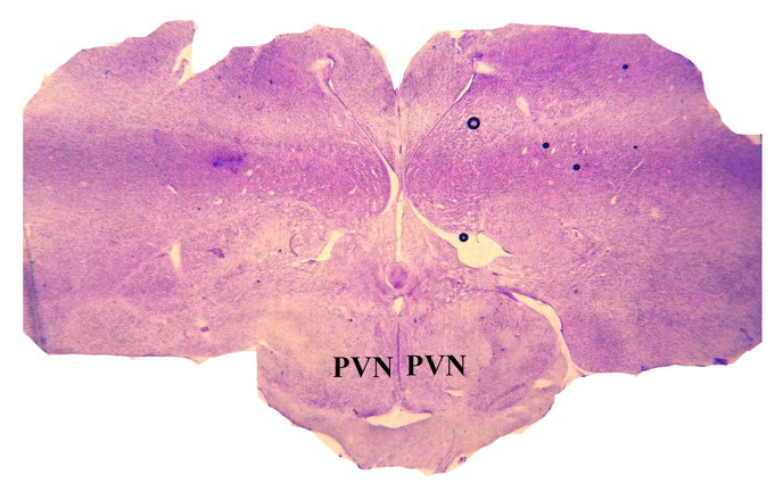

A

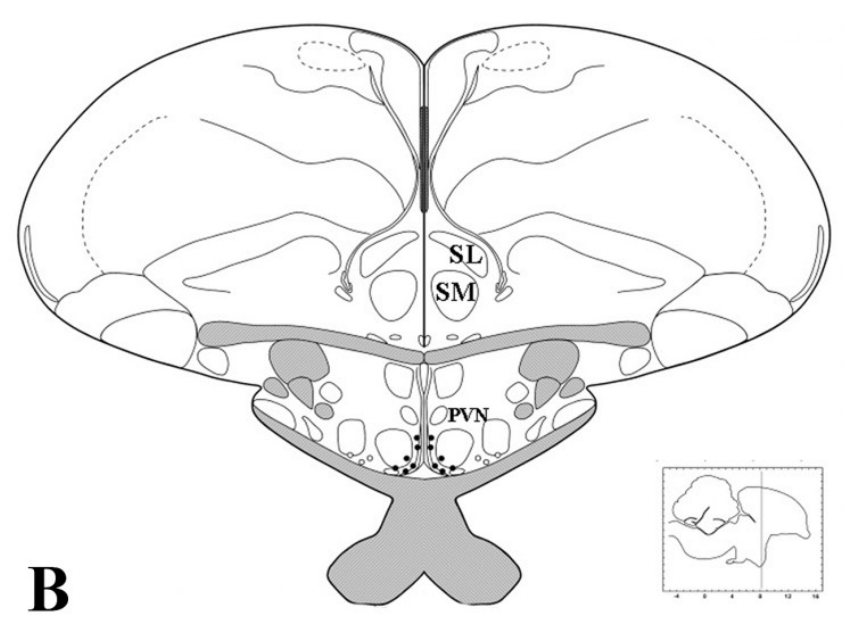

Figure 1. A) cresyl violet-stained slices of partridge and B) schematic drawing of regions containing paraventricular nuclei (PVN) of the chicken hypothalamus (Kuenzel, 2015). SL) lateral septal are; SM) medial septal area.

Statistical analysis

Data were subjected to the KolmogorovSmirnov normality test and analyzed using the PROC
MIXED (SAS Institute, Cary, NC, USA, 2002). Mean comparison was performed using the Tukey-Kramer test $(\mathrm{P}<0.05)$. The mean \pm SE number of GnIH-ir neurons is reported in the text. 

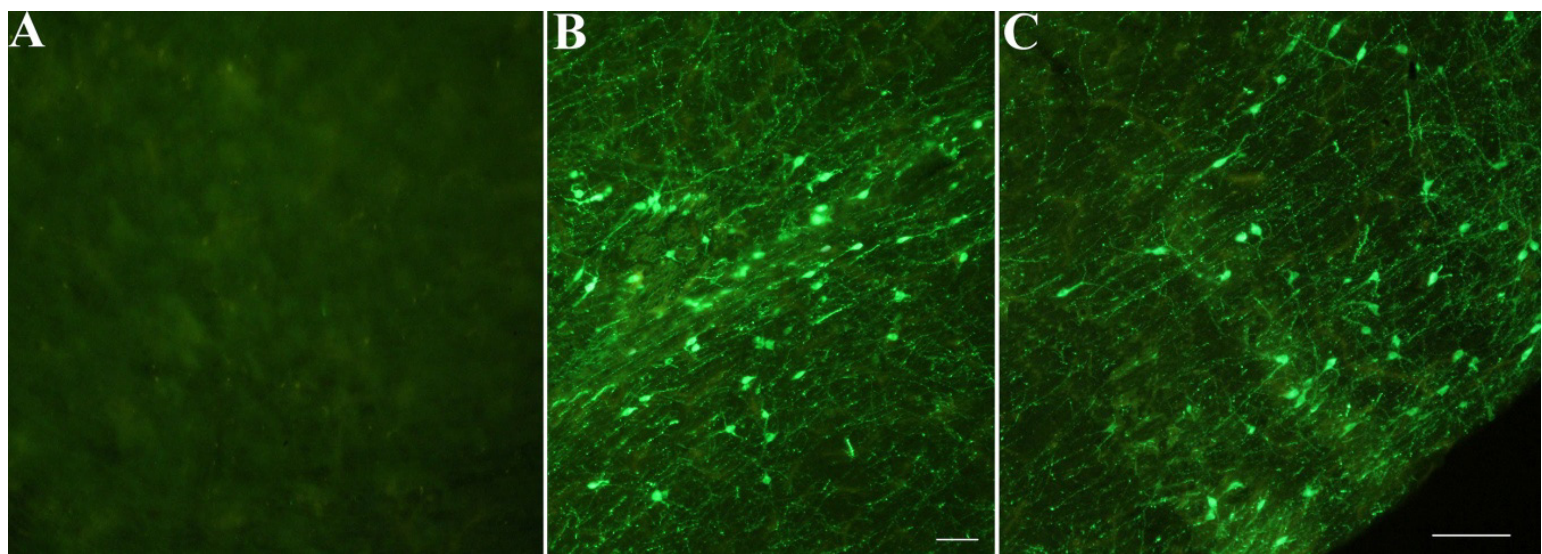

Figure 2. Immunohistochemistry staining using anti-quail gonadotropin inhibitory hormone (GnIH) antibody incubated with A) synthetic quail $\mathrm{GnIH}$ in a saturating concentration $(20 \mu \mathrm{g} / \mathrm{ml})$; B) synthetic human neuropeptide FF (NPFF) at $10 \mu \mathrm{g} / \mathrm{ml}$ and CC synthetic human KiSS-10 at $10 \mu \mathrm{g} / \mathrm{ml}$.

\section{Results}

Condensed populations of GnIH-ir neurons were identified in the PVN of male and female partridges (Fig. 3), and few GnIH-ir cell bodies were detected in the dorsomedial nucleus (DMN; Fig. 4A).
The GnIH projections were observed throughout the diencephalon with dense fibers at the medial preoptic area (MPOA), median eminence especially external layer (Fig. 4B), medial and lateral septal areas (Fig. 4C), optic tectum, around the tectal ventricle, bed nucleus of stria terminalis (BNST), and hippocampus.
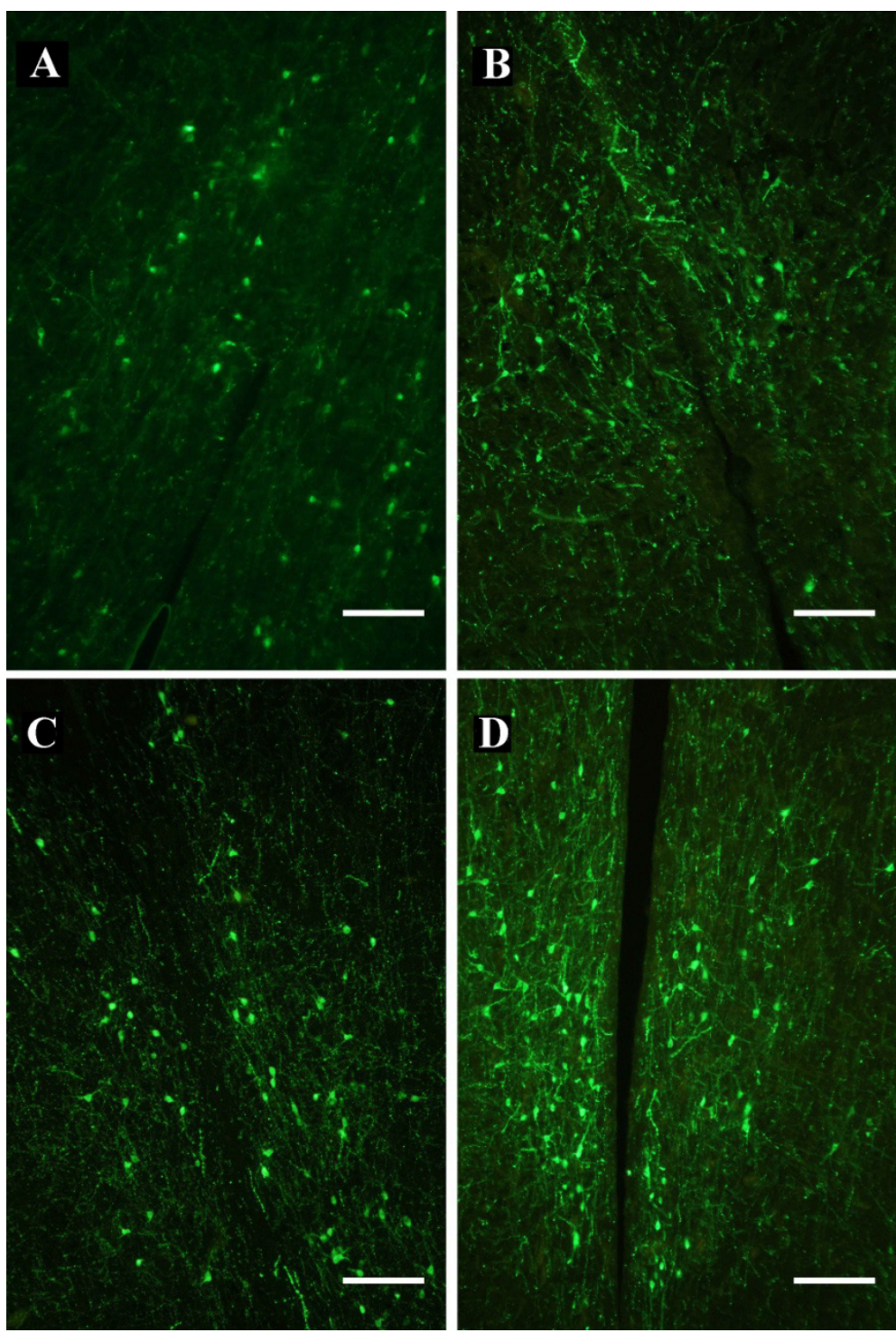

Figure 3. Immunohistochemical expression of gonadotropin inhibitory hormone $(\mathrm{GnIH})$ in neuronal cell bodies of the paraventricular nucleus (PVN) of the hypothalamus in the chukar partridge. A) female partridge in the breeding season; B) male partridge in the breeding season; C) female partridge in the non-breeding season; D) male partridge in the non-breeding season (scale bar $=100 \mu \mathrm{m}$ ). 
There were no sex differences in the number of GnIH-ir neurons in the PVN (Fig. 5A). The number of $\mathrm{GnIH}$-ir neurons was lower in the breeding season than in the non-breeding season (Fig. 5B) in both males and females (Fig. 5C). In male and female partridges, the mean weight and volume of the gonads were significantly higher in the breeding season than in the non-breeding season (Fig. 6).

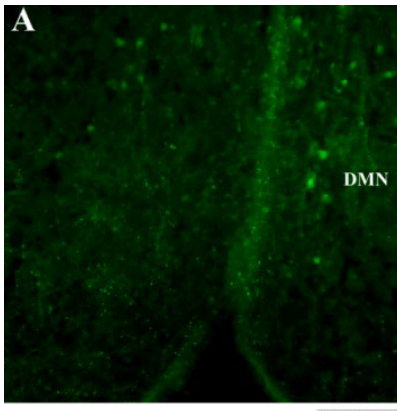

D

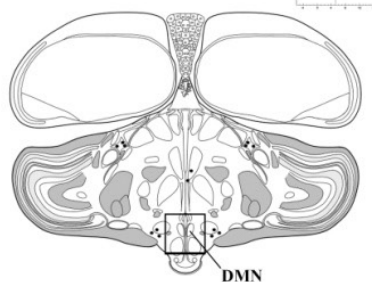

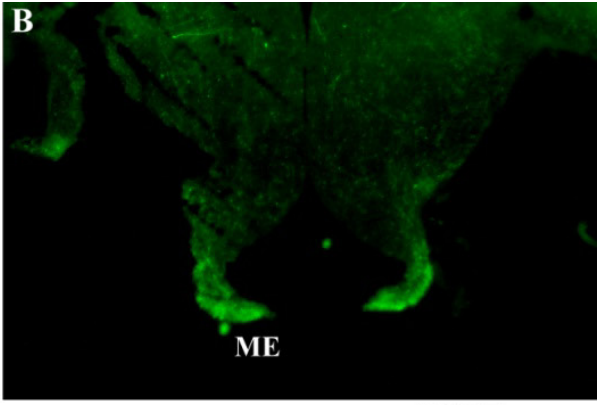

E

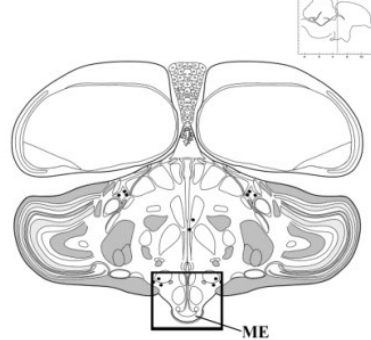

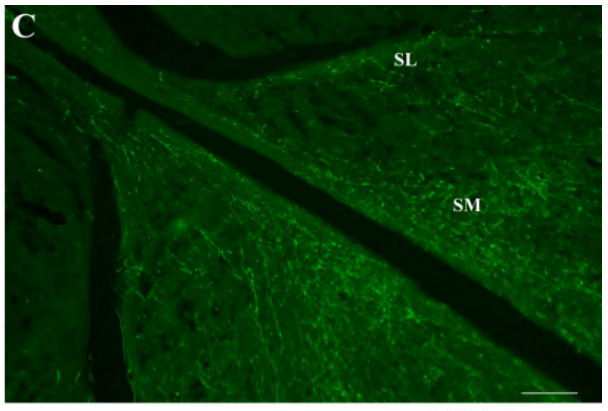

F

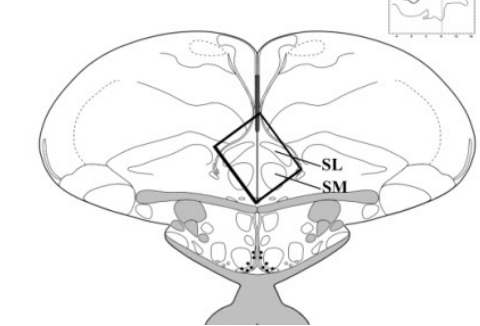

Figure 4. Immunohistochemical expression of gonadotropin inhibitory hormone $(\mathrm{GnIH})$ in $\mathrm{A})$ dorsomedial nucleus (DMN) of the hypothalamus in the chukar partridge; B) dense GnIH fibers at the median eminence (ME); and C) medial and lateral septal area (ME and SM, respectively). D, E, and F) schematic drawings of regions in the chicken hypothalamus (Kuenzel, 2015).
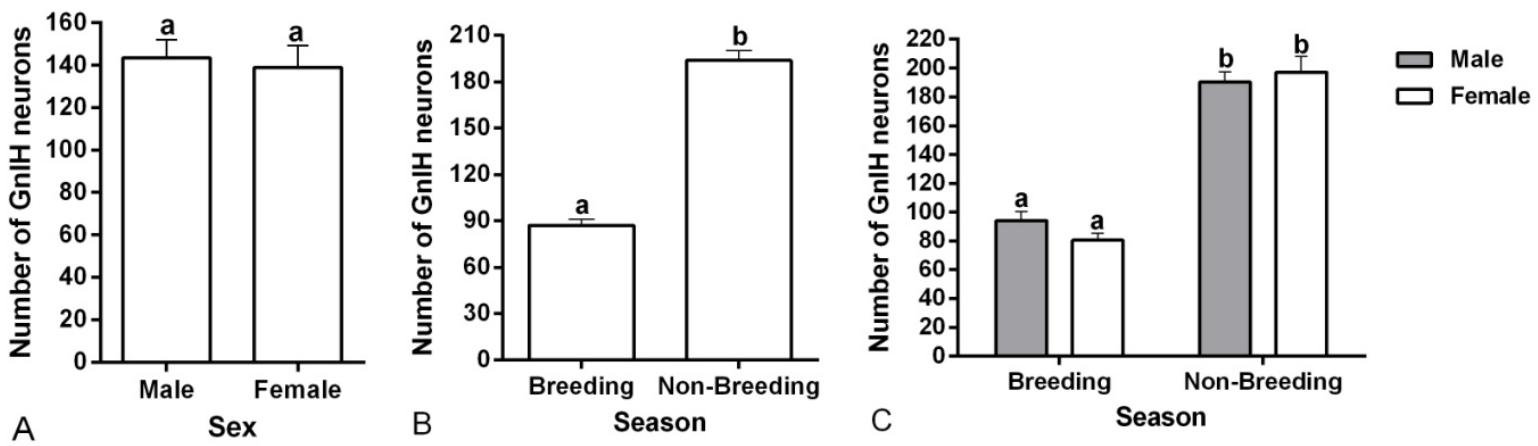

Figure 5. A) The number (mean $\pm \mathrm{SE}$ ) of gonadotropin inhibitory hormone $(\mathrm{GnIH})$ expressing neurons in the paraventricular nucleus $(\mathrm{PVN})$ of male and female partridges $(\mathrm{n}=10)$. B) Number of GnIH expressing neurons in the PVN during the breeding and non-breeding seasons $(n=10)$. C) Number of GnIH expressing neurons in the PVN of male and female chukar partridges during the breeding and non-breeding seasons $(n=5)$. 

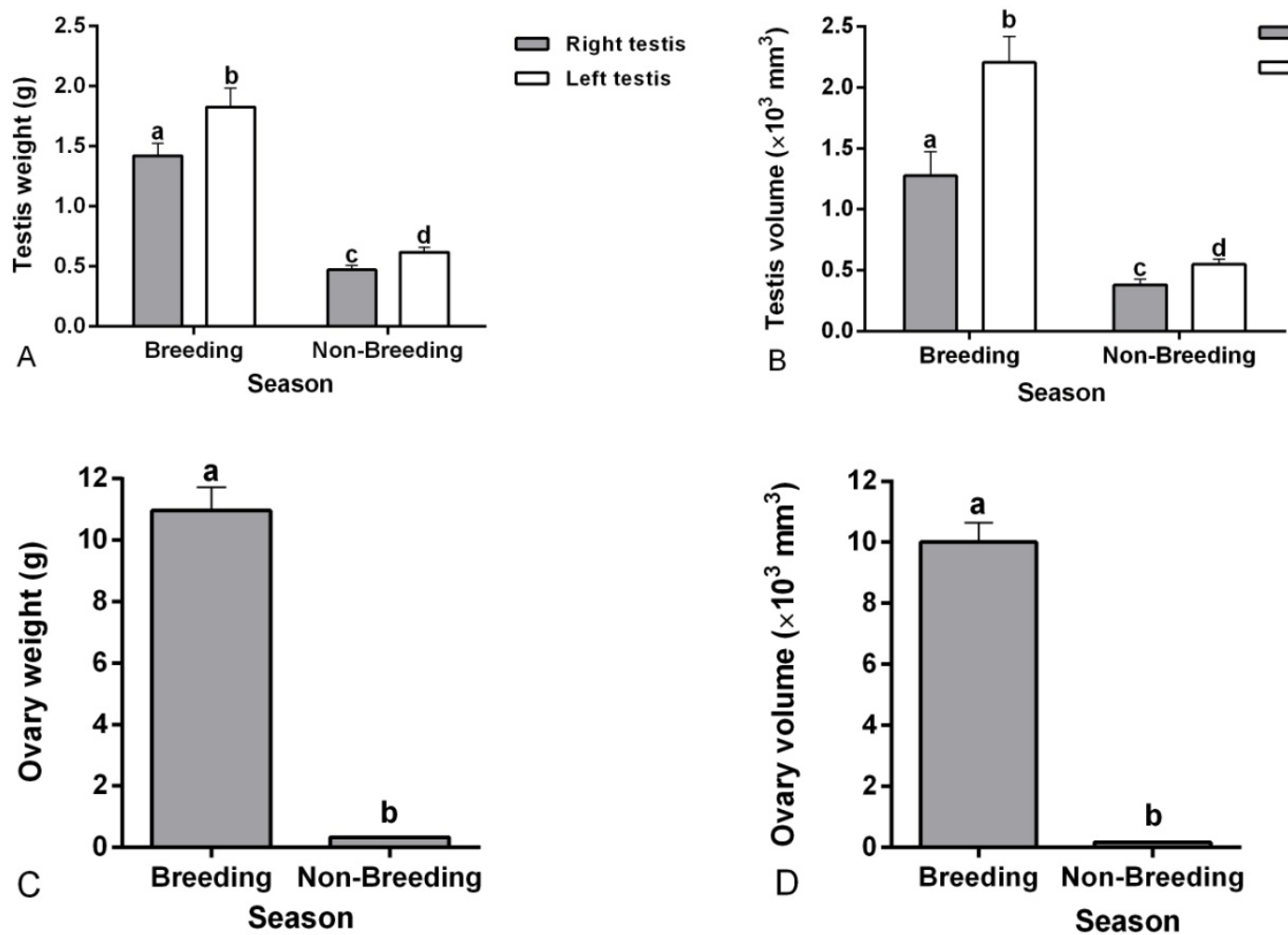

Figure 6. Mean $\pm \mathrm{SE}$ of $\mathrm{A}$ ) testis weight, B) testis volume, C) ovary weight and D) ovary volume in the Chukar partridge during the breeding and non-breeding seasons.

\section{Discussion}

The present study showed that GnIH-ir neurons were primarily found in PVN of both male and female partridges as already were reported in quail (Tsutsui et al., 2000; Ubuka et al., 2003), song and house sparrows (Bentley et al., 2003), white crowned sparrows (Osugi et al., 2004; Ubuka et al., 2012), and European starlings (Ubuka et al., 2008). Few GnIH positive neurons were also observed in DMN, consistent with the findings in zebra finch (Tobari et al., 2010) and sparrow (Small et al., 2008). GnIH-ir fibers were found throughout the diencephalon with dense fibers in the POA and median eminence. It has been shown that GnRH-I neurons in the POA of the European starling express GPR147 (GnIH receptor) mRNA, and that GnIH neurons interact directly with GnRH-I neurons (Ubuka et al., 2008); therefore, GnIH neurons in the partridge might also directly affect GnRH neurons although hypothalamic gonadotropin-releasing hormone content did not change in red-legged partridge maintained on $8 \mathrm{~L}: 16 \mathrm{D}$ or 20L:4D and was only elevated by photostimulation in the females (Creighton, 1988). On the other hand, GnIH-ir fibers were suggested to be present in the median eminence of quail (Ukena et al., 2003), sparrows (Bentley et al., 2003; Osugi et al., 2004), and European starlings (Ubuka et al., 2008), and GPR147 (GnIH receptor) expression in the pituitary gland was reported in the chicken (Maddineni et al., 2008). Based on the in vivo (Osugi et al., 2004; Ubuka et al., 2006) and in vitro (Ciccone et al., 2004; Maddineni et al.,
2008) studies, demonstrating an inhibitory effect of GnIH on LH secretion, the effect of GnIH on the partridge pituitary gonadotropes is also a possibility. Therefore in chukar partridges, GnIH during nonbreeding season might suppress reproductive function via inhibitory effects on GnRH neurons and gonadotropic cells, simultaneously.

In line with other reports (Ukena et al., 2003; Calisi et al., 2008; McGuire et al., 2013a), no significant differences were found in the number of GnIH neurons in the PVN of male and female partridges. In the present study, the number of $\mathrm{GnIH}$-ir neurons was lower in the breeding season than in nonbreeding season in both male and female partridges. Previous studies reported that GnIH neurons were decreased in photostimulated sparrows (Bentley et al., 2003) and $\mathrm{GnIH}$ expression in the hypothalamic explants was lower in quail exposed to long days (Ubuka et al., 2005; Chowdhury et al., 2010) along with decreases in plasma LH concentration (Chowdhury et al., 2010) and in testicular weight (Ubuka et al., 2005). Thus, GnIH may capable of transducing photoperiodic information and influencing the reproductive axis in both male and female partridges.

Melatonin expression decreases during the long days (Ubuka et al., 2005; Chowdhury et al., 2010). Importantly, GnIH neurons in the PVN express Mel1c, a melatonin receptor subtype in quail (Ubuka et al., 2005). Because pinealectomy combined with orbital enucleation decreased the expression of $\mathrm{GnIH}$ in the diencephalon and melatonin implants had an opposite 
effect in quail, melatonin derived from the pineal gland and eyes acts directly on GnIH neurons via Mellc to induce $\mathrm{GnIH}$ expression and release in bird (Ubuka et al., 2005; Chowdhury et al., 2010). Based on these findings, it has been speculated that elevated melatonin during the short days have positive effect on $\mathrm{GnIH}$ neurons which in turn suppress the reproductive axis (Ubuka et al., 2005; Bentley et al., 2010; Chowdhury et al., 2010). On the other hand, during long days, melatonin and $\mathrm{GnIH}$ decrease and the reproductive functions reactivate (for reviews, see Tsutsui, 2009; Tsutsui et al., 2010, 2013). Therefore, it is also reasonable that $\mathrm{GnIH}$ and melatonin act together to regulate seasonal breeding in the partridge since reproductive functions are photosensitive in this species (Woodard et al., 1986; Creighton, 1988).

The volume of testes and ovaries was increased significantly in the breeding season in comparison to the non-breeding season. This finding is in line with results of McGuire et al. (2011, 2013b) in the European starling which have proposed that melatonin acts via Mellc and Mellb receptors in the testis to seasonally regulate the expression and action of the gonadal $\mathrm{GnIH}$ system, which modulates testosterone.

In conclusion, our results revealed that, $\mathrm{GnIH}$ expressing neurons located in the PVN and DMN of partridge hypothalamus and its expression is photosensitive but not sex-dependence. Based on distribution of $\mathrm{GnIH}$ fibers through the diencephalon and seasonal expression of the neuropeptide, it seems that $\mathrm{GnIH}$ neurons play part in regulating the seasonal breeding in long (breeding season) and short days (nonbreeding season) in the hypothalamus of male and female chukar partridge.

\section{Acknowledgments}

This research was financially supported by the Shiraz University Vice-Chancellor for Research (grant number: tez2219611, 2014).

\section{References}

Bentley GE, Perfito N, Ukena K, Tsutsui K, Wingfield JC. 2003. Gonadotropin-inhibitory peptide in song sparrows (Melospiza melodia) in different reproductive conditions, and in house sparrows (Passer domesticus) relative to chicken-gonadotropin-releasing hormone. J Neuroendocrinol, 15:794-802.

Bentley GE, Ubuka T, McGuire NL, Calisi R, Perfito N, Kriegsfeld LJ, Wingfield JC, Tsutsui K. 2009. Gonadotrophin-inhibitory hormone: a multifunctional neuropeptide. J Neuroendocrinol, 21:276-281.

Bentley GE, Tsutsui K, Kriegsfeld LJ. 2010. Recent studies of gonadotropin-inhibitory hormone $(\mathrm{GnIH})$ in the mammalian hypothalamus, pituitary and gonads. Brain Res, 1364:62-71.

Calisi RM, Rizzo NO, Bentley GE. 2008. Seasonal differences in hypothalamic EGR-1 and $\mathrm{GnIH}$ expression following capture-handling stress in house sparrows (Passer domesticus). Gen Comp Endocrinol, 157:283-287.
Chowdhury VS, Yamamoto K, Ubuka T, Bentley GE, Hattori A, Tsutsui K. 2010. Melatonin stimulates the release of gonadotropin-inhibitory hormone by the avian hypothalamus. Endocrinology, 151:271-280.

Chowdhury VS, Tomonaga S, Nishimura S, Tabata S, Cockrem JF, Tsutsui K, Furuse M. 2012. Hypothalamic gonadotropin-inhibitory hormone precursor mRNA is increased during depressed food intake in heat-exposed chicks. Comp Biochem Physiol, 62:227-233.

Ciccone NA, Dunn IC, Boswell T, Tsutsui K, Ubuka T, Ukena K, Sharp PJ. 2004. Gonadotrophin inhibitory hormone depresses gonadotrophin alpha and follicle-stimulating hormone beta subunit expression in the pituitary of the domestic chicken. $J$ Neuroendocrinol, 16:999-1006.

Creighton JA. 1988. Photoperiodic control of puberty in the red-legged partridge (Alectoris graeca chukar). Gen Comp Endocrinol, 71:17-28.

Jafarzadeh Shirazi MR, Pazoohi F, Zamiri MJ, Salehi MS, Namavar MR, Tamadon A, Tanideh N, Zarei A, Tsutsui K. 2013. Expression of RFamiderelated peptide in the dorsomedial nucleus of hypothalamus during the estrous cycle of rats. Physiol Pharmacol, 17:72-79.

Jafarzadeh Shirazi MR, Zamiri MJ, Salehi MS, Moradi S, Tamadon A, Namavar MR, Akhlaghi A, Tsutsui K, Caraty A. 2014. Differential expression of RFamide-related peptide, a mammalian gonadotrophininhibitory hormone orthologue, and kisspeptin in the hypothalamus of Abadeh ecotype does during breeding and anoestrous seasons. $J$ Endocrinol, 26:186-194.

Kriegsfeld LJ, Ubuka T, Bentley GE, Tsutsui K. 2015. Seasonal control of gonadotropin-inhibitory hormone $(\mathrm{GnIH})$ in birds and mammals. Front Neuroendocrinol, 37:65-75.

Kuenzel W. 2015. Chicken brain atlas. Series [monograph on the Internet]. Durham, NC: Duke University. Available on: http://www.avianbrain.org/ nomen/Chicken_Atlas.html. Accessed on: 30 June 2016. Maddineni S, Ocón-Grove OM, Krzysik-Walker SM, Hendricks Iii GL, Proudman JA, Ramachandran R. 2008. Gonadotrophin-inhibitory hormone receptor expression in the chicken pituitary gland: potential influence of sexual maturation and ovarian steroids. $J$ Neuroendocrinol, 20:1078-1088.

McGuire NL, Kangas K, Bentley GE. 2011. Effects of melatonin on peripheral reproductive function: regulation of testicular $\mathrm{GnIH}$ and testosterone. Endocrinology, 152:3461-3470.

McGuire NL, Ferris JK, Arckens L, Bentley GE, Soma KK. 2013a. Gonadotropin releasing hormone $(\mathrm{GnRH})$ and gonadotropin inhibitory hormone $(\mathrm{GnIH})$ in the songbird hippocampus: regional and sex differences in adult zebra finches. Peptides, 46:64-75.

McGuire NL, Koh A, Bentley GE. 2013b. The direct response of the gonads to cues of stress in a temperate songbird species is season-dependent. PeerJ, 1:e139.

Osugi T, Ukena K, Bentley GE, O'Brien S, Moore IT, Wingfield JC, Tsutsui K. 2004. Gonadotropininhibitory hormone in Gambel's white-crowned sparrow (Zonotrichia leucophrys gambelii): cDNA identification, 
transcript localization and functional effects in laboratory and field experiments. $J$ Endocrinol, 182:33-42.

Small TW, Sharp PJ, Bentley GE, Millar RP, Tsutsui K, Mura E, Deviche P. 2008. Photoperiodindependent hypothalamic regulation of luteinizing hormone secretion in a free-living Sonoran desert bird, the Rufous-winged Sparrow (Aimophila carpalis). Brain Behav Evol, 71:127-142.

Tobari Y, Iijima N, Tsunekawa K, Osugi $\mathbf{T}$, Okanoya K, Tsutsui K, Ozawa H. 2010. Identification of gonadotropin-inhibitory hormone in the zebra finch (Taeniopygia guttata): Peptide isolation, cDNA cloning and brain distribution. Peptides, 31:816-826.

Tsutsui K, Saigoh E, Ukena K, Teranishi H, Fujisawa Y, Kikuchi M, Ishii S, Sharp PJ. 2000. A novel avian hypothalamic peptide inhibiting gonadotropin release. Biochem Biophys Res Commun, 275:661-667.

Tsutsui K. 2009. A new key neurohormone controlling reproduction, gonadotropin-inhibitory hormone $(\mathrm{GnIH})$ : Biosynthesis, mode of action and functional significance. Prog Neurobiol, 88:76-88.

Tsutsui K, Bentley GE, Bedecarrats G, Osugi T, Ubuka T, Kriegsfeld LJ. 2010. Gonadotropin-inhibitory hormone $(\mathrm{GnIH})$ and its control of central and peripheral reproductive function. Front Neuroendocrinol, 31:284295

Tsutsui K, Ubuka T, Bentley GE, Kriegsfeld LJ. 2013. Review: regulatory mechanisms of gonadotropininhibitory hormone $(\mathrm{GnIH})$ synthesis and release in photoperiodic animals. Front Neurosci, 7:60.

Ubuka T, Ueno M, Ukena K, Tsutsui K. 2003.
Developmental changes in gonadotropin-inhibitory hormone in the Japanese quail (Coturnix japonica) hypothalamo-hypophysial system. $J$ Endocrinol, 178:311-318.

Ubuka T, Bentley GE, Ukena K, Wingfield JC, Tsutsui K. 2005. Melatonin induces the expression of gonadotropin-inhibitory hormone in the avian brain. Proc Natl Acad Sci USA, 102:3052-3057.

Ubuka T, Ukena K, Sharp PJ, Bentley GE, Tsutsui K. 2006. Gonadotropin-inhibitory hormone inhibits gonadal development and maintenance by decreasing gonadotropin synthesis and release in male quail. Endocrinology, 147:1187-1194.

Ubuka T, Kim S, Huang Y-c, Reid J, Jiang J, Osugi T, Chowdhury VS, Tsutsui K, Bentley GE. 2008. Gonadotropin-inhibitory hormone neurons interact directly with gonadotropin-releasing hormone-I and -II neurons in European starling brain. Endocrinology, 149:268-278.

Ubuka T, Mukai M, Wolfe J, Beverly R, Clegg S, Wang A, Hsia S, Li M, Krause JS, Mizuno T, Fukuda Y, Tsutsui K, Bentley GE, Wingfield JC. 2012. RNA interference of gonadotropin-inhibitory hormone gene induces arousal in songbirds. PLoS One, 7:e30202.

Ukena K, Ubuka T, Tsutsui K. 2003 Distribution of a novel avian gonadotropin-inhibitory hormone in the quail brain. Cell Tissue Res, 312:73-79.

Woodard AE, Hermes JC, Fuqua CL. 1986. Effects of light conditioning on reproduction in partridge. Poult Sci, 65:2015-2022. 